\title{
Remedies for breach of contract under the United Nations Convention on the International Sale of Goods
}

\author{
Christiana Fountoulakis
}

Published online: 17 November 2010

(C) ERA 2010

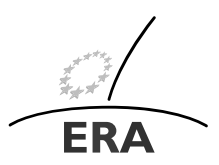

EUROPÄISCHE RECHTSAKADEMIE ACADEMY OF EUROPEAN LAW ACADEMIE DE DROIT EUROPEEN ACCADEMIA DI DIRITTO EUROPEO TRIER - TREVES - TREVIRI

\begin{abstract}
The article provides an overview of the remedies available under the United Nations Convention on the International Sale of Goods. A short introduction to the Convention is followed by an analysis of the structure and the basic features of the Convention's remedies system. The article then deals with the various remedies in detail and presents them in their context. The circumstances in which a particular remedy will be available are explained, as are the requirements for the various remedies, and whether a party in breach of contract can prevent the other party's use of the remedy. At the same time, the article emphasises the questions to which satisfactory answers have not yet been provided, and makes suggestions as to what the appropriate solutions should be. The article finishes with an appreciation of the Convention's remedies system and some future prospects.
\end{abstract}

Keywords UN Convention on the International Sale of Goods (CISG) - Remedies · Breach of contract · Parties' rights and duties · Failure to perform

\section{Introduction}

The United Nations Convention on the International Sale of Goods (CISG) is the most successful international instrument in the field of commercial law. It was drafted by the United Nations Commission for International Trade Law (UNCITRAL) in 1980. Since then, it has been enacted in 76 Contracting States, among them all major trading

This paper is based on the presentation given by the author at the ERA conference on International Commercial Transactions, held on 10-11 June 2010 in Trier.

Prof. Dr. iur. C. Fountoulakis $(\bowtie)$

Lehrstuhl für Privatrecht, Universität Fribourg, Beauregard 11, 1700 Fribourg, Switzerland

e-mail: Christiana.Fountoulakis@unifr.ch 
nations, such as the USA, China, India, Germany and Russia. ${ }^{1}$ Turkey will join on 1 August 2011, ${ }^{2}$ and Brazil and Portugal will follow soon. The only noticeable absentee among European countries is the United Kingdom. ${ }^{3}$

The Convention covers, in principle, approximately $80 \%$ of all international sales contracts. ${ }^{4}$ An estimated 3,000 published court decisions and arbitral awards and an abundance of scholarly writing, numerous conferences, and other events ${ }^{5}$ show the prominent role the CISG plays in legal practice, legal science, and legal education. Furthermore, the CISG has influenced many international and national laws. At the international level, the UNIDROIT Principles of International Commercial Contracts, the Principles of European Contract Law (PECL), the EC Directive on Certain Aspects of the Sale of Consumer Goods, ${ }^{6}$ and the OHADA ${ }^{7}$ General Commercial Act ${ }^{8}$ have all heavily relied on the CISG. At the domestic level, the CISG has served as a model for revisions made to the law of contract of the Baltic States, several Eastern European jurisdictions and, in particular, China. The original, basic concept of the modernisation of the German law of obligations ${ }^{9}$ was also borrowed from the Convention.

One reason for the success of the Convention is the way in which its provisions on remedies are structured. An approach was chosen in the Convention which focuses on the consequences of a breach rather than on its origin. The starting point is a "failure to perform any of [one's] obligations under the contract or this Convention" 10 . This failure to perform may consist of late performance, lack of conformity of the goods, of a breach of duties of information or duties of care, etc. The Convention uses one single formula to describe the violation of contractual obligations. The only additional element used to qualify the breach of contract relates to its severity: if the

\footnotetext{
${ }^{1}$ An overview of the contracting states can be found at http://www.uncitral.org/uncitral/en/uncitral_texts/ sale_goods/1980CISG_status.html (last accessed on 6 November 2010).

2 Id.

${ }^{3}$ For an examination of the reasons why the United Kingdom has not adopted the CISG, see Bridge [6], pp. 17,18 et seq.

${ }^{4}$ The Convention applies where both parties (i.e., seller and buyer) have their respective places of business in contracting states (Article 1 para. 1(a)) or where the applicable conflict of laws rules lead to the application of the law of a contracting state (Article 1 para. 1(b)), except where the parties have excluded the application of the Convention. For the possibility of derogating from or modifying the provisions of the CISG see below, at Sect. 2.

${ }^{5}$ The annual Willem C. Vis International Commercial Arbitration Moot is one such event. It takes place in Vienna (and, for a few years, also in Hong Kong) and is, after the medical congress 'Der KongressMedizin in Wien', the biggest annual event in Vienna.

${ }^{6}$ Directive 99/44/EC of the European Parliament and of the Council of 25 May 1999 on certain aspects of the sale of consumer goods and associated guarantees.

${ }^{7}$ Organisation pour l'Harmonisation en Afrique du Droit des Affaires/Organisation for the Harmonisation of Business Law in Africa.

${ }^{8}$ Acte Uniforme sur le Droit Commercial Général/Uniform Act Relating to General Commercial Law.

${ }^{9}$ Gesetz zur Modernisierung des Schuldrechts of 26 November 2001, BGB1. I 3138. For the impact of the Convention on the German law reform see Schlechtriem [21].

${ }^{10}$ Articles 45 para. 1, 61 para. 1 CISG.
} 
breach is 'fundamental', ${ }^{11}$ the aggrieved party may choose from a larger palette of remedies than if the breach is a 'simple' one. ${ }^{12}$ The integrative terminology which has been chosen by the Convention avoids overly theoretical debates about the cause of the breach and turns the attention to the question which is the really important one in legal practice - the rights available to either of the parties in case of breach of contract.

The way in which the remedies are chosen, structured, and conceptualised in the Convention is a real masterpiece. The CISG was the first legal instrument to introduce certain key elements which, since then, have been applied and copied with great success, such as a clear-cut remedies concept, a fortunate combination of civil law and common law approaches, simple terminology, and the avoidance of overly formal procedures. Moreover, the remedies system of the CISG is regarded as providing a fair balancing of the parties' interests and has won favour with many domestic laws and international unification projects. ${ }^{13}$

This article gives a general view of the remedies under the Convention. It starts with an overview of the parties' rights in the event of a breach of contract. The salient features of the remedies system adopted by the CISG are then dealt with and thereafter the various remedies are discussed in detail.

\section{Overview of the remedies available}

The following table depicts the remedies available to either buyer or seller in the event of a breach (or impending breach) of contract. These remedies are the default rules provided for by the Convention; nothing hinders the parties from agreeing on other or further remedies or a modified set of remedies in the case of a breach of contract. ${ }^{14}$ As can be seen from the table below, the seller has 'fewer remedies', but not because the CISG is particularly buyer-friendly, but rather because certain remedies only make sense in the case of the buyer.

\footnotetext{
${ }^{11}$ For the definition of 'fundamental breach' see Article 25 CISG:

"A breach committed by one of the parties is fundamental if it results in such detriment to the other party as substantially to deprive him of what he is entitled to except under the contract, unless the party in breach did not foresee and a reasonable person of the same kind in the same circumstances would not have foreseen such a result."

${ }^{12}$ For details see below, at Sects. 3.1, 4.

${ }^{13}$ For a recent overview see Schwenzer/Hachem [24], pp. 457, 461 et seq.

${ }^{14} \mathrm{Cf}$. Article 6 CISG: "The parties may (...) derogate from or vary the effect of any of its provisions." As to the economic efficiency aspect of contracting into remedial arrangements see Katz [14], pp. 378, 390 et seq.
} 


Buyer Seller

- Right to specific performance

- Right to payment or specific performance

- Right to avoid the contract

- Right to avoid the contract

- Right to damages

- Right to damages

- Right to interest

- Right to interest

- Right to suspend performance

- Right to suspend performance

- Right to repair

- Right to replacement of goods

(substitute delivery)

- Right to diminution of price

Fig. 1 Overview of buyer's and seller's remedies for breach of contract

\section{Structure and basic features of the Convention's remedies concept}

The Convention has opted for certain basic rules and principles which apply to all of the remedies for which the CISG provides.

\subsection{Principle of Pari Passu remedies}

A first salient feature of the remedies system of the CISG is the fact that the rights available to the injured party in case of breach, are, in principle, on an equal footing with each other. None of the remedies is superior, and none of them is inferior. They are all at the injured party's disposal, and the aggrieved party can freely choose that remedy which will be most appropriate to meet its interests. There are two exceptions to the principle of 'remedies equality'. The right to terminate the contract-so-called 'avoidance'-will only be available to either of the parties if the breach of contract is 'fundamental', that is, if the very basis of the contract has been shaken. ${ }^{15}$ Similarly, the right to require substitute goods is reserved to cases of fundamental breach.

\subsection{Principle of combinability of damages and other remedies}

A second characteristic of the remedies available under the CISG is that all of them can be combined with damages. ${ }^{16}$ A party who terminates the contract, for instance, can, in addition, claim compensation for damages suffered due to the (fundamental) breach of contract. The same holds true for the party who seeks to obtain performance of the contract: any damages resulting out of the non-performance of the other party can be claimed in addition to performance. The list could be extended at will.

\footnotetext{
${ }^{15}$ For the legal definition of 'fundamental breach' see above, footnote 11.

${ }^{16}$ Articles 45 para. 2, 61 para. 2 CISG: "The buyer/seller is not deprived of any right he may have to claim damages by exercising his right to other remedies."
} 
A combination of remedies other than damages is not possible because relying on both of them would be contradictory: the buyer who seeks performance will not, at the same time, require replacement or a diminution of the contract price. A seller who claims payment of the purchase price will not, at the same time, avoid the contract. However, it is perfectly possible that those remedies, which exclude each other if applied simultaneously, be exercised consecutively, one after the other. The buyer, for example, who first claims performance-that is, delivery of the goodsand then finds out that the goods finally delivered are defective, may seek replacement or diminution of the price.

\subsection{Principle of self-help remedy}

The Convention subscribes to the concept that the rights which it grants are exercised by way of declaration made to the other party. It has rejected both the concept that a party's rights must be asserted by way of a judicial claim as well as the concept that rights are effectuated ipso facto, automatically. ${ }^{17}$ The remedies available under the Convention are thus self-help devices, exercised by way of unilateral, informal notification of the other party. This self-help or declaration model is efficient, as it avoids costly and time-consuming judicial procedures. At the same time, the selfhelp approach does justice to the need for legal certainty, which would not be the case if a breach of contract automatically triggered legal consequences which would not have to be communicated to the party in breach.

\subsection{Principle of notification}

A forth basic structural element is the principle of notification. In order to be able to rely on any of the remedies provided for in the Convention, the buyer who has received goods must, in principle, have examined the goods "within as short a period as is practicable in the circumstances" 18 and notified any non-conformity of the goods-specifying the nature of the lack of conformity- "within a reasonable time". ${ }^{19}$ There are exceptions to the examination and notification requirement, ${ }^{20}$ but these exceptions are applied restrictively. ${ }^{21}$

The rationale of the principle of notification is that the seller must be given a chance to remedy the defect if it is reasonable and not inconvenient in the circumstances. ${ }^{22}$ The same rationale can be found with regard to preliminary remedies. If

\footnotetext{
${ }^{17}$ See Bianca/Bonell/Date-Bah [5], at Article 26 note 2.

${ }^{18}$ Article 38 para. 1 CISG.

${ }^{19}$ Article 39 para. 1 CISG.

${ }^{20} \mathrm{Cf}$. Articles 40, $44 \mathrm{CISG}$. According to Article $40 \mathrm{CISG}$, the lack of notifying the seller of the nonconformity of the goods does not deprive the buyer of its remedies if the seller knew or ought to have known of facts that could lead to the non-conformity of the goods and did not disclose those facts to the buyer. Article 44 CISG entitles the buyer to claim a reduction of the price or damages (except for loss of profit) if it has a 'reasonable excuse' for his failure to give the required notice.

${ }^{21}$ See Martinez Cañellas [16], pp. 261, 266; Honnold [13], \$261 in fine.

${ }^{22}$ See, for many, Schlechtriem/Schwenzer/Schwenzer [23], ad Article 38 para. 4.
} 
a party fears that the other party will not perform in time, it can suspend its performance, but it must notify the other party first. ${ }^{23}$ Similarly, a party which wants to avoid the contract because of an anticipatory fundamental breach must give notice of its intention to avoid the contract, except where the party in future breach has made it clear that it will not perform. ${ }^{24}$

\subsection{Principle of precedence of right to cure}

The principle of notification, taken on its own, would not live up to the rationale of granting the seller a second chance to perform properly. It is only by virtue of a second fundamental rule that the seller's 'chance for second tender' is safeguarded, namely by the principle that the seller's right to cure takes precedence over the buyer's right to exercise a remedy. The buyer cannot claim replacement of goods, reduction of the price, or termination of the contract without having given the seller the opportunity to cure the defect in the goods. ${ }^{25}$ Similarly, the sum which the buyer is entitled to claim as damages will be the loss which remains after the seller's efforts to cure the defect. ${ }^{26}$ With regard to the buyer's remedy of claiming repair, the question of whether the seller's right to cure takes precedence does not emerge, as both parties aim at the same result; the question of how repair will be supplied will be decided by the seller as the party with the specific expertise. The question of how the seller's right to cure and the buyer's claim for specific performance interrelate is not raised either, as the seller's right to cure presupposes that (defective) performance has been made. If the seller's performance has not yet become due but the buyer wishes to exercise a preliminary remedy, the principle of the seller's right to cure taking priority over the buyer's exercise of remedies is modified accordingly: the seller's issuance of adequate assurance that it will perform the contract properly cuts off the buyer's right for avoidance or suspension of performance.

The rule that the buyer's remedies are put on hold as long as the seller enjoys a right to cure "reflects what merchants do in the real world of commerce"27 and avoids useless transaction costs.

\footnotetext{
${ }^{23}$ Article 71 para. 3 CISG. ad Article 72 para. 17-18. Herber/Czerwenka [12], ad Article 48 para. 11.

${ }^{26}$ Cf. Staudinger/Magnus [15], ad Article 48 para. 31.

${ }^{27}$ Bridge [6], pp. 17, 28.
}

${ }^{24}$ Article 72 para. 2 CISG. For the dispute concerning the question of legal consequences if no notice is given under Articles 71 or 72 see, e.g., Schlechtriem/Schwenzer/Fountoulakis [23], ad Article 71 para. 34;

${ }^{25}$ For the interrelation of the seller's right to cure and the buyer's right to reduce the price, cf. Article 50 CISG, second sentence; for the respective interplay with regard to the buyer's right to avoid the contract, cf., for many, CISG-AC Opinion no 5 [1], para. 4.4; Fountoulakis [9], p. 160 et seq.; Ferrari [8], p. 489, pp. 500-501, with further references. The precedence of the seller's right to cure over the buyer's right to claim replacement of the goods results from the argument that replacement of goods requires a fundamental breach, whereas, as long as the defect can be cured, the breach of contract has not become fundamental, see Bianca/Bonell/Will [5], ad Article 48 note 3.1.2; Schlechtriem/Schwenzer/Müller-Chen [23], ad Article 48 para. 20; Audit [3], note 133; for differing views see Staudinger/Magnus [15] ad Article 48 para. 32; 


\section{The remedies in detail}

In the section which follows, the principles underlying the remedies concept of the Convention are concretised by a more detailed analysis of the various remedies.

\subsection{Right to performance}

The seller's duties of performance are described in Article 30 CISG. According to this provision, " $[\mathrm{t}]$ he seller must deliver the goods, hand over any documents relating to them and transfer the property in the goods, as required by the contract and this Convention." If the seller does not comply with any of these duties, the buyer has the right to require performance. ${ }^{28}$ The buyer may thus demand that the contract be executed by the seller as agreed.

Similar rules can be found with regard to the obligations incumbent on the buyer. Article 53 CISG states that " $[t]$ he buyer must pay the price for the goods and take delivery of them as required by the contract and this Convention." Should the buyer not perform its duties, the seller "may require the buyer to pay the price, take delivery or perform his other obligations..."29

The Convention provides thus for the remedy of specific performance-a remedy with which continental-European jurisdictions are familiar but which, traditionally, is an exception in common law jurisdictions. ${ }^{30}$ It may appear that in drafting the Convention, the representatives of the Roman law tradition prevailed over the common law jurisdictions. But this impression is deceptive: hidden among other socalled 'General Provisions', Article 28 CISG permits a court not to enter a judgment for specific performance if the domestic law of the country in which the court is located would not provide for such a remedy. ${ }^{31}$ Thus, whenever specific performance is sought by judicial means, the outcome will, in the first place, depend on the admissibility of this remedy under the Convention, but, in the second place, also on whether specific performance would be granted under the lex fori. An English court, for example, when confronted with a claim for specific performance under a CISG contract, must consult English law first and examine whether English law would allow for specific performance in the case at hand. ${ }^{32}$ As is generally known, specific performance in English law is an equitable remedy and still regarded as exceptional. It will be granted only if damages are not an adequate remedy for the breach of contract at hand. ${ }^{33}$ In contrast, a German court would find nothing extraordinary in

\footnotetext{
${ }^{28}$ Cf. Article 46 CISG para. 1 CISG: "The buyer may require performance by the seller of his obligations unless the buyer has resorted to a remedy which is inconsistent with this requirement."

${ }^{29}$ Article 62 CISG.

${ }^{30}$ See, for many, Bianca/Bonell/Lando [5], ad Article 28 note 1.1.

${ }^{31}$ Article 28 CISG: "If, in accordance with the provisions of this Convention, one party is entitled to require specific performance of any obligation by the other party, a court is not bound to enter a judgment for specific performance unless the court would do so under its own law in respect of similar contracts of sale not governed by this Convention."

${ }^{32}$ The courts are obliged to examine the case under the lex fori and do not have the liberty not to consult their own domestic law, see Schlechtriem/Schwenzer/Müller-Chen [23], ad Article 28 para. 20.

${ }^{33}$ Hanbury/Martin [11], para 24-013 et seq.; Peel [19], para 21-016 et seq.
} 
upholding a claim for specific performance (if all the requirements are met), because the right to insist on specific performance is, metaphorically speaking, the 'spine' of the German law of obligations. ${ }^{34}$ However, it should be noted that a court whose lex fori would not grant specific performance in the case at hand is not bound to reject an action for specific performance under the Convention; it is up to the lex fori to determine whether there is room for discretion, ${ }^{35}$ and it is suggested that many courts that would incline against specific relief in domestic cases may incline towards it in CISG cases, out of a sense of international comity or out of a desire to establish a favourable environment for international business. ${ }^{36}$

Of course, there are fears that Article 28 CISG encourages forum shopping. However, as case law, which now stretches back over thirty years, shows, the role of Article 28 has been marginal, ${ }^{37}$ because commercial parties (whether from a common law background or not) seem to insist on specific performance only when other remedies are inadequate. Therefore, the fact that the Convention has opted for granting specific relief does not lead to a noticeable clash between the Convention and the common law.

\subsection{Right to repair}

Article 28 CISG applies not only to an action for specific performance, but also to an action for repair or replacement of goods. ${ }^{38}$ As is the case with specific performance, if repair or replacement are sought extra-judicially, as a matter of informal unilateral communication from buyer to seller, they are an absolutely valid remedy; however, if they are claimed judicially, the question of whether they will succeed will depend on whether the court would grant such remedy under its own law.

The right to repair is a right which, by nature, is reserved to the buyer. If the goods do not conform to the contract, the buyer may require the seller to remedy the lack of conformity by repair, unless this is unreasonable in light of the circumstances. ${ }^{39}$ The reasonableness test will typically be linked to costs: if the costs of repairing the goods are disproportionately higher than the costs of acquiring a substitute, or if the expenditure is incommensurate with the advantage which the buyer will derive from removal of the defect, the reasonability of requiring repair must be denied. ${ }^{40}$

\footnotetext{
${ }^{34}$ The term was coined by Ernst Rabel in: Recht des Warenkaufs, vol. I, 1936, at 375 ("Erfüllungsanspruch als Rückgrat der Obligation").

${ }^{35}$ Schlechtriem/Schwenzer/Müller-Chen [23], ad Article 28 para. 22.

${ }^{36}$ Cf. Honnold [13], para. 195; Katz [14], p. 378, p. 384.

${ }^{37}$ The largest database on the Convention, the Pace Database on the CISG and International Commercial Law (http://www.cisg.law.pace.edu/), lists only seven cases in which Article 28 was mentioned (but not necessarily applied) (last accessed on 6 November 2010).

${ }^{38}$ Schlechtriem/Schwenzer/Müller-Chen [23], ad Article 28 para. 6.

${ }^{39}$ Article 63 para. 3 CISG.

${ }^{40}$ See, e.g., Piltz [20], para. 5-188; MünchKommHGB/Benicke [18], ad Article 46 para. 22.
} 


\subsection{Right to replacement of the goods}

If the buyer wishes to have the defective goods replaced, it must demonstrate that the lack of conformity of the goods constitutes a fundamental breach of contract. ${ }^{41}$ Replacement of the goods can not be claimed in every case of defective goods. The situation must be such that the buyer cannot reasonably be expected to keep the goods and have them repaired, or keep the goods unrepaired and declare itself satisfied with damages and/or price reduction. ${ }^{42}$ The German Bundesgerichtshof made this clear in a decision of 1996: the test is "whether other processing or the sale of the goods in the normal course of business, even if perhaps with a discount in price, is possible and reasonable without disproportionate expense." 43

\subsection{Right to diminution of the price}

A third remedy which, by nature, is available only to the buyer is the right to reduce the price. ${ }^{44}$ This remedy is familiar to the civil law jurist: most continental European sales laws provide for the remedy of contract price reduction in the event of the delivery of defective goods. ${ }^{45}$ In contrast, price reduction is a remedy unknown to common law jurisdictions. In Anglo-American sales laws, a claim for damages is used to obtain the result of the buyer paying less for goods that do not conform to the contract. ${ }^{46}$ Interestingly, the CISG also provides for the right to damages. Price reduction and damages co-exist, which raises the question why price diminution has been introduced into the CISG at all, as the same practical result can be achieved by a claim for damages. A first reason for adopting the remedy of price reduction is that diminution of the price will be available regardless of whether the seller's failure to deliver conforming goods causes any loss to the buyer. A second reason may be that, if a buyer invokes the right of price reduction, the seller cannot argue that there was an impediment within the meaning of Article 79 CISG which would exempt the seller from its liability. ${ }^{47}$ Finally, the remedy of price reduction might also be of interest to the seller: the amount by which the price is diminished corresponds to the ratio between the value that the goods actually delivered had and the value they were supposed to have. ${ }^{48}$ This calculation method allows for some additional amount of risk sharing between the seller and the buyer, because a possible deviation of the original contract price from the objective (market) value of the goods is maintained.

\footnotetext{
${ }^{41}$ Article 46 para. 2 CISG.

${ }^{42}$ See Bianca/Bonell/Will [5], ad Article 46 note 2.2.2.2; Staudinger/Magnus [15], ad Article 46 para. 61; Schlechtriem/Schwenzer/Müller-Chen [23], ad Article 46 para. 40.

${ }^{43}$ BGH, 3 April 1996, BGHZ 132, 290, 298, CISG-online 135 (www.cisg-online.ch).

${ }^{44}$ Article 50 CISG.

${ }^{45}$ Cf., e.g., $\$ 442$ German BGB; Art. 1644 French Code Civil; Art. 205 Swiss Code of Obligations.

${ }^{46}$ Cf. Benjamin [4], para. 17-045 et seq.

${ }^{47}$ For the impediment beyond one's control which exempts from liability see below, at Sect. 4.5.5.

${ }^{48}$ The established formula is to multiply the value of the delivered goods multiplied by the contract price and to divide that sum by the hypothetical value of conforming goods.
} 
The buyer need not assert its claim for diminution of the price before a court or arbitral tribunal, and the remedy does not depend on a fundamental breach. However, prior to exercising the remedy of reduction of the price, the seller must be given the opportunity to cure the defect in the goods or any other failure in its performance, if this does not cause the buyer unreasonable inconvenience (Article 48). ${ }^{49}$

\subsection{Right to avoid the contract}

\subsubsection{In case of actual breach}

The right to terminate the contract (so-called 'avoidance') will be available in two situations: either the breach committed by the other party is 'fundamental', or it has become clear that the contract will not be performed at all.

Thus, the first alternative is to show that the breach of contract suffered is affecting the very basis of the contract (Article 25 CISG). This will entitle the aggrieved party to set aside the contract. ${ }^{50}$ In this respect, the seller's right to cure a breach, which has been mentioned above, takes precedence: in the case-law and literature, the prevailing view is that, as long as there is a possibility of curing the defect without causing the buyer unreasonable inconvenience, the breach of contract is not a fundamental one. ${ }^{51}$

The second alternative is to terminate the contract because the other party does not perform its core obligations. ${ }^{52}$ The term 'core obligations'- which is not a technical term under the Convention-is used here to make it clear that not every nonperformance of contractual obligations will give raise to a claim for avoidance of the contract: the non-performance must relate to the seller's obligation to deliver the goods, or to the buyer's duty to pay or take delivery of the goods. ${ }^{53}$ As a side observation, it may come as a surprise to the representatives of the Germanic jurisdictions that the Convention considers the buyer's duty to take delivery of the goods as a core obligation, breach of which could trigger the seller's right to avoid the contract. ${ }^{54}$ Not performing within the contractually-agreed period will not yet as such constitute a fundamental breach, except for cases where time is of the essence and the other party was aware of that time constraint. ${ }^{55}$ Therefore, in case of non-performance, the creditor must first fix an additional period of time within which the debtor may perform. ${ }^{56}$ If the latter fails to do so within this additional period, or if it makes it clear while the additional period is running that it will not perform, the creditor can

\footnotetext{
${ }^{49}$ See also above, at Sect. 3.5 .

${ }^{50}$ See Articles 49 para. 1(a); 64 para. 1(a) CISG.

${ }^{51}$ See the references above, at footnote 25 .

${ }^{52}$ See Articles 49 para. 1(b); 64 para. 1(b) CISG.

${ }^{53}$ See the wording in Articles 49 para. 1(b); 64 para. 1(b) CISG.

${ }^{54}$ In the Germanic jurisdictions, there is no independent sanction for failure to take delivery of the goods; that is, unless otherwise agreed, the buyer cannot claim that the buyer be ordered to take delivery (as a kind of specific performance), cf., for many, MünchKomm/Kramer [17], Introduction, para. 50.

${ }^{55}$ See, for many, CISG-AC, Opinion no 5 [1], para. 4.4.

${ }^{56}$ Article 49 para. 1(b) in connection with Article 47 CISG.
} 
avoid the contract. This mechanism has been borrowed from the Germanic and Roman jurisdictions and is therefore sometimes also known as the Nachfrist model. ${ }^{57}$ The additional period must be of "reasonable length". 58 If the period is unreasonably short, it will be considered as triggering a period of reasonable length; if the creditor avoids the contract after the elapsing of an unreasonably short period, the creditor commits itself a breach of contract. 59

Avoidance of the contract is a remedy of last resort, because avoidance raises additional costs for return transport and insurance which are useless transaction costs. The ultima ratio character of avoidance makes itself felt not only by qualified requirements, but also in view of Article 51 para. 2 CISG, which states that avoidance of the entire contract is only permitted if the breach amounts to a fundamental breach of the entire contract.

\subsubsection{In case of pending breach}

So far, the right to terminate the contract has been discussed in relation to situations where performance is due and performance either does not take place or does take place but not as it should. However, the right to avoid the contract exists also where the contractual obligations have not yet become due and where there are strong indications that the other party will commit a fundamental breach in the future. This situation is the so-called anticipatory breach. ${ }^{60}$

It has been noted that the Convention has adopted several concepts from civil law jurisdictions: the right to claim specific performance, the right to price reduction, the right to avoid the contract after the lapse of an additional period of time (Nachfrist model). ${ }^{61}$ Although, in those cases, it is actually only the original idea which has been borrowed from the civil law and, furthermore, significant, common law influenced modifications have been made in substance, it might be reassuring to know that the concept of anticipatory breach is a remedy truly rooted in the common law. ${ }^{62}$

Anticipatory breach stands for the right of both buyer and seller to declare the contract avoided if, prior to the date for performance of the contract, it is clear that the other party will commit a fundamental breach. ${ }^{63}$ The exercise of the right of avoidance in case of anticipatory breach is based on a prognosis: it must be 'clear', as Article 72(1) states, that the contract will be fundamentally breached by the other party. The threshold applied by courts and arbitral tribunals is high. For example, it must be

\footnotetext{
${ }^{57}$ See Secretariat Commentary, ad Article 43 Comment 8 ("Nachfrist, mise en demeure").

${ }^{58}$ Article 47 para. 1; Article 63 para. 1 CISG.

${ }^{59}$ See MünchKommBGB/Huber [17], ad Article 47 para. 13.

${ }^{60}$ There is a further possibility for avoidance of the contract before performance is due, which will not be dealt with here: Article 73 para. 2 CISG entitles the buyer to avoid an installment contract for the future if the seller's breach of contract with regard to an installment gives the buyer "good grounds to conclude that a fundamental breach of contract will occur with respect to future installments".

${ }^{61}$ Above at Sects. 4.1, 4.4, 4.5.1.

${ }^{62}$ For the common law origin of anticipatory breach, see, for many, Bianca/Bonell/Bennett [5], ad Article 72 note 1.4 .

${ }^{63}$ Article 72 para. 1 CISG.
} 
clear that the seller will not deliver because it lost its production facilities, or it must be clear that the buyer will not pay because of subsequent payment restrictions. ${ }^{64}$ In such a case, the party which fears it will soon be the victim of a fundamental breach must, in principle, ${ }^{65}$ give notice to the other party in order to permit it to provide adequate assurance. 66

\subsubsection{Declaration of avoidance}

Once a right of avoidance has been established, the party wishing to resort to that remedy must declare avoidance of the contract. The Convention is clearly against an ipso facto avoidance, which would automatically extinguish the contract once the requirements of contract avoidance are met. ${ }^{67}$ For example, under some national laws, such as Swiss or former German law, the fact that a contract will never be performed because its performance was impossible from the beginning renders the contract automatically invalid, without requiring that the impossibility or the ineffectiveness of the contract be asserted by one of the parties. ${ }^{68}$ Matters are different under the Convention, and rightly so, as the declaration model clearly enhances legal certainty and predictability.

The declaration may also consist of simple, non-legal language; the courts are usually generous in this respect. For example, a letter which stated that "the glass is full" and "enough is enough" was considered as declaration of avoidance. ${ }^{69}$ The declaration of avoidance may also be implicit, as long as it is sufficiently clear that the way in which the creditor is acting at that moment implies communication of avoidance. $^{70}$

\subsubsection{Restitution and accounting for benefits}

4.5.4.1 Restitution If the contract has been declared avoided, each party can claim restitution of what it has performed under the contract. The buyer can claim back the purchase price; the seller can claim return of the goods. For the buyer who wishes to terminate the contract there is one more obstacle: it cannot do so if it cannot make restitution of the goods substantially in the condition in which it received them. ${ }^{71}$ This rule is of Roman law origin and is still present in many civil law sales laws:

\footnotetext{
${ }^{64}$ For further illustrations cf. Schlechtriem/Schwenzer/Fountoulakis [23], ad Article 72 para. 11; Staudinger/Magnus [15], ad Article 72 para. 6.

${ }^{65}$ Article 72 para. 3 provides for an exception from the duty to give notice where it has been made clear by the debtor that it will not perform its obligations.

${ }^{66}$ Article 72 para. 2 CISG. This will typically be a bank guarantee, for details see Staudinger/Magnus [15], ad Article 71 para. 48 et seq.

${ }^{67}$ See above, at Sect. 3.3.

${ }^{68}$ See Article 20 para. 1 Swiss Code of Obligations; former $\$ 306$ of the German BGB.

${ }^{69}$ RB Kortrijk, 4 June 2004, CISG-online 945.

${ }^{70}$ See, e.g., Audiencia Provincial Castellòn, 21 March 2006, CISG-online 1488; OLG Karlsruhe, 19 December 2002, IHR 2003, 125, CISG-online 817.

${ }^{71}$ Article 82 para. 1 CISG. 
avoidance is excluded if the goods have been destroyed or damaged or changed so that they cannot be returned substantially in the original condition. ${ }^{72}$ The principle of restitution in natura is a weak point in the Convention, as it is scarcely suited for modern international sales laws. It comes as no surprise that the UNIDROIT Principles, the PECL, and the Draft Common Frame of Reference (DCFR) did not follow the Convention in this respect and chose to provide for the option to make restitution in money instead. ${ }^{73}$

Fortunately, the principle of restitution in natura is made subject to considerable modifications in the Convention. According to paragraph 2 of Article 82 CISG, avoidance is still possible (a) if it is not the buyer's responsibility that the goods cannot be returned substantially in the original state; (b) if the goods perished or deteriorated in the course of the examination of the goods as required in Article 38 CISG; or (c) if the goods were sold, consumed or transformed in the normal course of business before the lack of conformity was or ought to have been discovered by the buyer.

4.5.4.2 Accounting for benefits Restitution is complemented by an equalisation of benefits. The rationale of equalising benefits is that the parties should be put in the same economic position in which they were prior to performing their respective contractual obligations. ${ }^{74}$ The seller, in addition to paying back the purchase price, must also pay interest on it, from the date on which the price was paid. ${ }^{75}$ The buyer, along with returning goods, must account for all benefits which it has derived from the goods. $^{76}$

Article 84 CISG is troubling in certain respects for both courts and scholars. A first uncertainty relates to the duty to pay interest. The Convention does not state any interest rate, either in Article 84 or in the general rule on interest, Article 78. The reason for leaving the issue of the interest rate open is that no consensus could be found at the Drafting Conference; there were incompatible views, not only of an economic or political nature, but also, and more particularly, with regard to philosophical and religious ways of thinking. ${ }^{77}$ The solution found in Article 84 (and also in Article 78) was the least common denominator: there should be a duty to pay interest, but the interest rate was not defined. This raises a first difficulty with regard to the application of Article 84: numerous approaches have been suggested for the determination of the interest rate, from the application of interest rates which find world-wide acceptance to a direct or analogous application of the respective rules under unification projects or to the resort to domestic law. ${ }^{78}$ The answer to the question is still in flux. A sec-

\footnotetext{
${ }^{72}$ Cf., e.g., Article 207 Swiss Code of Obligations; Articles 391-394 Greek Civil Code; Art. 1647(1) French Code Civil.

${ }^{73}$ Article 7.3.6 para. 1, second sentence, UNIDROIT Principles; Article 9:309 PECL; Article III.-3:511 paras. 3, 4 DCFR.

${ }^{74}$ Schlechtriem/Schwenzer/Fountoulakis [23], ad Article 84 para. 3; Staudinger/Magnus [15], ad Article 84 para. 1.

${ }^{75}$ Article 84 para. 1 CISG.

${ }^{76}$ Article 84 para. 2 CISG.

${ }^{77}$ Schlechtriem [22], para. 317.

${ }^{78}$ See Schlechtriem/Schwenzer/Fountoulakis [23], ad Article 84 para. 16 et seq.; Staudinger/Magnus [15], ad Article 84 para. 9.
} 
ond uncertainty is whether, if the court or arbitral tribunal arrives at determining the interest rate applicable under Article 84 para. 1 CISG, the same interest rate should also apply under Article 78 CISG. The question could be answered in the affirmative at first blush for reasons of efficiency; but then the question emerges why the Convention provides for the duty to pay interest in two different provisions (Article 84 and Article 78). No consensus has been found to date.

The buyer's duty to account for benefits (Article 84(2)) is similarly unclear. What types of benefits should be accounted for? How are benefits to be calculated if restitution takes place by way of exception, that is, despite the fact that the goods cannot be returned in an unimpaired condition? ${ }^{79}$ What kind of costs incurred by the buyer when using the goods or otherwise drawing benefits from them can be deducted from the sum to be paid to the seller? What about foregone benefits-are they to be accounted for? These are questions that have not yet been clearly answered. ${ }^{80}$

\subsubsection{Right to damages}

Damages are the most important remedy in practice, because they provide for monetary relief, which is more easily enforced against local assets or against an issuer of a letter of credit than specific reliefs, such as performance, substitution, or repair. ${ }^{81}$

Most civil law jurisdictions require that, in order to be able to claim damages, the other party must have been at fault. The Convention follows the common law approach, which requires no fault on behalf of the party in breach. ${ }^{82}$ The aggrieved party can claim all sorts of damages suffered as a consequence of the breach, as long as the loss was foreseeable as a possible consequence of the breach. Article 74 CISG uses a simple but powerful formula: damages "consist of a sum equal to the loss, including loss of profit, suffered as a consequence of the breach". The provision aims at putting the aggrieved party in as good a position as if the party in breach had properly performed the contract. The essential basic concept is the principle of full compensation. ${ }^{83}$ As can be imagined, the calculation of damages available in case of breach raises many questions, such as what kind of loss should be compensated or where the limits of foreseeability of the loss must be drawn. In recent times, the discussion has reached a new dimension by challenging the very purpose of damages: whereas, until recently, damages were exclusively considered as compensation for economic loss, they are now also being discussed as mechanisms of preventing and punishing contract violations which do not cause any economic loss. ${ }^{84}$

The Convention provides for special rules for the calculation of damages where the contract has been avoided and a cover purchase has been undertaken ${ }^{85}$ or where a

\footnotetext{
${ }^{79} \mathrm{Cf}$. Article 82 para. 2 CISG and above, at Sect. 4.5.4.1.

${ }^{80}$ See also Bridge [7], ("considerable capacity to surprise by throwing up problems that have not been foreseen.").

${ }^{81}$ See Katz. [14], pp. 378-386.

${ }^{82} \mathrm{Cf}$., for many, Schlechtriem [22], para. 286.

${ }^{83}$ Cf. CISG-AC, Opinion no 6 [2], Comment 1.

${ }^{84}$ Disgorgement of profits is such an example for expanding the remedy of damages, see Schlechtriem/Schwenzer/Schwenzer [23], ad Article 74 para. 43.

85 Article 75 CISG.
} 
cover purchase has not been undertaken but a current market price exists. ${ }^{86}$ There is a duty to mitigate damages, ${ }^{87}$ as an expression of fair dealing in international trade, which is frequently evoked in legal practice. ${ }^{88}$ No damages must be paid if the debtor is exempt from liability due to an impediment which lies beyond its control. ${ }^{89}$

\subsubsection{Interest}

The second last point on the remedies list is the right to interest. "If a party fails to pay the price or any other sum that is in arrears, the other party is entitled to interest on it." 90 It has been mentioned that the interest rate applicable has not been settled in the Convention and that there are manifold suggestions as to how to determine it. ${ }^{91}$ In practice, the question is usually solved by having recourse to national law. ${ }^{92}$

\subsubsection{Right to suspend performance}

The right to suspend performance is a preliminary remedy which is usually neglected in scholarly writing, although it is of great practical importance: if it is highly probable that the other party will not perform a "substantial part of [its] obligations" makes sense to grant the first party the right to suspend its own performance rather than having it perform and thereby knowingly exposing itself to the risk of not receiving in return what was contractually agreed on. Of late, the right of suspension has been the subject of much discussion, especially with a view to expand its application under the Convention. There have been efforts to turn the right of suspension (which has hitherto been limited in its scope) into a general remedy which would be available on each occasion when chances are-in all probability-small that the debtor will fulfil all its contractual duties. ${ }^{94}$

\section{Summary}

The remedies under the Convention can be summarised as follows: they are on an equal footing, with no remedy taking precedence over any other. They can be combined with damages. All of the remedies are self-help remedies that can be exercised

\footnotetext{
${ }^{86}$ Article 76 CISG.

${ }^{87}$ Article 77 CISG.

${ }^{88}$ The Pace Database on the CISG (footnote 37) cites some hundred cases (last accessed on 6 November 2010).

${ }^{89}$ Article 79 CISG.

${ }^{90}$ Article 78 CISG.

${ }^{91}$ Above, at Sect. 4.5.4.2; for details, see Schlechtriem/Schwenzer/Bacher [23], ad Article 78 para. 26 et seq.

${ }^{92}$ Staudinger/Magnus [15], ad Article 78 para. 12 et seq.; Schlechtriem/Schwenzer/Bacher [23], ad Article 78 para. 27, with further references.

${ }^{93}$ Article 71 para. 1 CISG.

${ }^{94}$ For details see Schlechtriem/Schwenzer/Fountoulakis [23], ad Article 71 para. 11-12.
} 


\begin{tabular}{lll}
\hline Unqualified remedies & Semi-qualified remedies & Fully qualified remedies \\
\hline $\begin{array}{l}\text { - Right to specific perfor- } \\
\text { mance (but see Article 28) }\end{array}$ & $\bullet$ Price reduction & $\begin{array}{l}\text { - Right to claim substi- } \\
\text { tute goods }\end{array}$ \\
- Interest & $\bullet$ Damages & $\begin{array}{c}\text { Right to avoid the con- } \\
\text { tract }\end{array}$ \\
& • Right to repair & \\
& $\bullet$ Right of suspension & \\
\hline
\end{tabular}

Fig. 2 Classification of remedies

by way of a unilateral, informal declaration, without having to assert the right in judicial proceedings. The availability and the extent of the buyer's remedies depend on whether the seller is able and willing to cure the defect without causing unreasonable inconvenience.

The remedies for which the Convention provides are subject to different levels of requirements. The right to interest and the right to claim specific performance depend on nothing more than simple non-payment or non-performance. They could therefore be deemed 'unqualified remedies' in that they are not subject to any other, specific requirement which would restrict their application. In contrast, the remedies of price reduction and damages are subject to more rigid requirements: they depend on the seller's failure to cure the defect. The right to claim repair requires that resorting to that remedy be reasonable. Also the right to the preliminary remedy of suspension of performance depends on a "substantial part" of the other party's obligations being likely to remain unperformed. Thus, all of these remedies can be grouped under the term 'semi-qualified remedies', in that something more than a mere breach of contract is required. The last group of remedies consists of the right to avoid the contract and the right to claim substitute delivery. The level of requirements is the highest for these remedies, as they require a (future) fundamental breach on behalf of the other party. They could be called 'fully qualified remedies'. The suggested classification can be tabulated as in Fig. 2.

\section{Final remarks}

The goal of this short overview is to familiarise European lawyers with the basic principles and rules of the remedies system of the CISG. There is a wealth of case law and scholarly writing which deals with particular questions in detail. The abundance of literature shows the immense level of interest the Convention has given rise to among the legal community. The discussion of specific points under the Convention assists not only in interpreting its provisions; it also benefits more recent supra- and international unification projects. It speaks for the quality of the remedies rules of the Convention that the UNIDROIT Principles, the PECL, and the DCFR adopted the remedies system of the CISG without making any substantial changes to it. Despite the fact that practitioners still hesitate to apply the Convention, for reasons that have 
been described elsewhere, ${ }^{95}$ with its well-balanced and elaborate remedies system, the CISG has nonetheless set the standard for national and international sets of rules.

\section{References}

1. Advisory Council, Opinion no 5: The buyer's right to avoid the contract in case of non-conforming goods or documents, 7 May 2005, http://www.cisgac.com/

2. Advisory Council, Opinion no 6: Calculation of Damages under CISG Article 74, Spring 2006, http://www.cisgac.com/

3. Audit, B.: La vente internationale de marchandises. Commentaire de la Convention des Nations Unies du 11 avril 1980. L.G.D.J., Paris (1990)

4. Benjamin, J.P.: In: Guest (ed.) Benjamin's Sale of Goods, 7th edn. Sweet \& Maxwell, London (2006)

5. Bianca, C.M., Bonell, M.J. (eds.): Commentary on the International Sales Law. Giuffré, Milan (1987)

6. Bridge, M.: A law for international sales. Hong Kong Law J. 37, 17-40 (2007)

7. Bridge, M.: The nature and consequences of avoidance of the contract under the United Nations Convention on the International Sale of Goods. Int. Law Rev. Wuhan Univ. 10, 118-128 (2008-2009)

8. Ferrari, F.: Fundamental breach of contract under the UN Sales Convention-25 Years of Article 25 CISG. J. Law Commer. 25, 489-508 (2006)

9. Fountoulakis, C.: Das Verhältnis von Nacherfüllungsrecht des Verkäufers und Vertragsaufhebungsrecht des Käufers im UN-Kaufrecht, Zeitschrift für Internationales Handelsrecht (IHR), pp. 160-168 (2003)

10. Fountoulakis, C.: The parties' choice of 'neutral law' in international commercial sales contracts. Eur. J. Law Reform VII(3/4), 303-329 (2005)

11. Hanbury, H.G., Martin, J.E.: Modern Equity, 17th edn. Sweet \& Maxwell, London (2005)

12. Herber, R., Czerwenka, B.: Internationales Kaufrecht, Kommentar zu dem Übereinkommen der Vereinten Nationen vom 11. April 1980 über Verträge über den internationalen Warenkauf. C.H. Beck, Munich (1991)

13. Honnold, J.O.: Uniform Law for International Sales under the 1980 United Nations Convention, 3rd edn. Kluwer Law International, The Hague (1999)

14. Katz, A.W.: Remedies for breach of contract under the CISG. Int. Rev. Law Econ. 25, 378-396 (2006)

15. Magnus, U.: von Staudinger, J. Kommentar zum Bürgerlichen Gesetzbuch mit Einführungsgesetz und Nebengesetzen, Wiener UN-Kaufrecht (CISG). Sellier-de Gruyter, Berlin (2005)

16. Martinez Cañellas, A.: The Scope of Article 44 CISG. J. Law Commer. 25, 261-271 (2005-2006)

17. Münchener Kommentar zum BGB, 5th edn. C.H. Beck, Munich (2007)

18. Münchener Kommentar zum HGB, 2nd edn. C.H. Beck, Munich (2007)

19. Peel, E.: Treitel's Law of Contracts, 12th edn. Sweet \& Maxwell, London (2007)

20. Piltz, B.: Internationales Kaufrecht, 2nd edn. C.H. Beck, Munich (2008)

21. Schlechtriem, P.: The German Act to Modernize the Law of Obligations in the Context of Common Principles and Structures of the Law of Obligations in Europe, Oxford University Comparative Law Forum at ouclf.iuscomp.org (2002)

22. Schlechtriem, P.: Internationales UN-Kaufrecht, 4th edn. Mohr Siebeck, Tübingen, (2007)

23. Schlechtriem, P., Schwenzer, I.: In: Schwenzer (ed.) Commentary on the UN Convention on the International Sale of Goods (CISG), 3rd edn. Oxford University Press, Oxford (2010)

24. Schwenzer, I., Hachem, P.: The CISG—successes and pitfalls. Am. J. Comp. Law 57, 457-478 (2009)

${ }^{95}$ Fountoulakis [10], pp. 303-317 et seq. 